\title{
PEMBELAJARAN BERBANTUAN PERMAINAN FORMULA 1 (RUN, JUMP, THROW) DALAM AKTIVITAS GERAK LOKOMOTOR DAN TINGKAT KEBUGARAN JASMANI SISWA SEKOLAH DASAR PADA MATA PELAJARAN PJOK
}

\author{
Heldie Bramantha', Dodik Eko Yulianto² \\ 1,2 Universitas Abdurachman Saleh Situbondo \\ E-mail: heldie_bramantha@unars.ac.id'1, dodik_eko@unars.ac.id² \\ DOI: https://doi.org/10.36526/kejaora.v5i2.992
}

\begin{abstract}
ABSTRAK
Penelitian dan pengembangan ini bertujuan untuk mengetahui kelayakan pengembangan model permainan formula 1 (Run, Jump, Throw), untuk mengetahui kemenarikan respon siswa terhadap pengembangan model permainan formula 1 (Run, Jump, Throw). Penelitian ini dilakukan menggunakan metode Research \& Development (R\&D) dengan menggunakan prosedur pengembangan Borg \& Gall. Teknik pengumpulan data menggunakan lembar angket validasi. Isntrumen yang digunakan berupa lembar angket validasi untuk mengetahui kelayakan model permainan formula 1 (Run, Jump, Throw) dan angket respon siswa untuk mengetahui kemenarikan siswa terhadap model permainan formula 1(Run, Jump, Throw). Teknik analisis data yang digunakan dalam penelitian pengembangan ini adalah menggunakan teknik deskriptif berbentuk persentase. Berdasarkan hasil validasi terhadap pengembangan model permainan formula 1 diperoleh skor ratarata kelayakan pengembangan model permainan formula 1 hasil validasi dari ahli penjas 1 diperoleh rata-rata4,2, pada ahli penjas 2 diperoleh rata-rata 4,3, dan pada ahli pembelajaran diperoleh ratarata 4,4. Dapat disimpulkan hasil validasi adalah termasuk dalam kriteria layak digunakan. Kemenarikan pengembangan model pembelajaran permainan formula 1(Run, Jump, Throw) diperoleh rata-rata pada uji coba skala kecil diperoleh prosentase $89,75 \%$, sedangkan pada uji coba skala besar diperoleh prosentasi 91\%. Dari hasil tersebut model permainan formula 1(Run, Jump, Throw) termasuk dalam kriteria "sangat menarik".
\end{abstract}

Kata Kunci: Pengembangan, Penjas, Permainan Formula 1 (Run, Jump, Throw)

\section{PENDAHULUAN}

Pendidikan jasmani merupakan bagian darikehidupan manusia, karena melalui pendidikan jasmani manusia dapat lebih banyak belajar hal yang berhubungan dengan afektif, kognitif, dan psikomotorik. Pada dasarnya pendidikan jasmani harus sudah ditanamkan sejak usia dini, karena pendidikan jasmani mempunyai pengaruh terhadap perkembangan anak, seperti yangtelah dijelaskan dalam BSNP (2006) berikut ini. Pendidikan Jasmani, Olahraga dan Kesehatan merupakan media untuk mendorong pertumbuhan fisik, perkembangan psikis, keterampilan motorik, pengetahuan dan penalaran, penghayatan nilai-nilai (sikap, mental, sosial, emosional, sportivitas, spritual), serta pembiasaan pola hidup sehat yang bermuara untuk merangsang pertumbuhan dan perkembangan kualitas fisik dan psikis yang seimbang. Menurut Husdarta (2011) pendidikan jasmani adalah proses pendidikan yang memanfaatkan aktivitas fisik danuntuk menghasilakan perubahan holistik dalam kualitas individu baik dalam hal fisik, mental serta emosional.

Pentingnya pendidikan jasmani dalam pola pendidikan di Indonesia telah dirumuskan oleh pemerintah berupa Undangundang No. 20 tahun 2003. Khusus mengenai kurikulum pendidikan dasar dan menengah telah dirumuskan pada pasal 42 yang wajib memuat mata-mata pelajaran sebagai berikut. (1) pendidikan agama, (2) pendidikan kewarganegaraan, (3) bahasa, (4) matematika, (5) ilmu pengetahuan alam, (6) ilmu pengetahuan sosial, (7) seni dan 
Jurnal Kejaora: Jurnal Kesehatan Jasmani dan Olah Raga

ISSN: 2541-5042 (Online)

ISSN: 2503-2976 (Print)

Volume 5 Nomor 2, Edisi November 2020

budaya, (8) pendidikan jasmani dan olahraga,

(9) keterampilan/kejuruan, dan (10) muatan lokal.

Inti dari pembelajaran pendidikan jasmani olahraga dan kesehatan untuk jenjang Sekolah Dasar adalah guru harus mampu membuat siswa untuk melakukan aktivitas gerak. Belajar gerak harus mulai diajarkan pada anak usia Sekolah Dasar. Belajar gerak adalah serangkaian proses latihan atau perubahan kemampuan dalam merespon yang relatif permanen. (Lutan;2002). Permasalahan yang terjadi adalah terjadinya perubahan kultur gerak bagi siswa sekolah dasar. Perubahan kultur gerak yang dimaksudkan adalah perubahan kebiasaan aktif bergerak menjadi kebiasaan kurang gerak atau fenomena yang sering dialami oleh anak-anak SD yaitu gaya hidup diam. Perubahan gaya hidup ini disebabkan oleh kemajuan teknologi komunikasi dan transportasi yang serba otomatis sehingga memudahkan berbagai aktivitas dalam kehidupan sehari- hari. Anak-anak yang fitrahnya disebut sebagai makhluk yang suka bermain (homo luden), menjadi sangat berkurang dan cenderung menghilangkan aktivitas fisik dalam berbagai kegiatan seharihari. Dapat dicontohkan misalnya dalam kehidupan sehari hari, anak-anak pergi ke sekolah menggunakan kendaraan yang tidak melakukan aktivitas fisik seperti sepeda motor atau mobil. Berbeda sekali seperti anak-anak SD era tahun 90'an,dimana anakanak ketik berangkat sekolah menggunakan kendaraan yang mengutamakan aktivitas fisik seperti sepeda ontel, bahkan ada juga yang berjalan kaki. Sebuah organisasi Kesehatan Dunia yang bernama WHO (2002) memperkirakan pada tahun 2021 sebanyak $74 \%$ kematian disebabkan oleh penyakit tidak menular atau sebanyak $61 \%$ disebabkan rendahnya kesegaran jasmani. Aktivitas jasmani merupakan sekolah kehidupan karena dapat mengajarkan nilai-nilai berupa keterampilan hidup yang esensial untuk kehidupan manusia. Oleh karena itu, aktivitas jasmani difasilitasi oleh institusi pendidikan melalui pembelajaran pendidikan jasmani dari mulai taman kanak-kanak, pendidikan dasar, menengah hingga pendidikan tinggi. (Husdarta,2011).

Salah satu komponen penting dari kesegaran jasmani adalah ketahanan jantung dan peredaran darah. Untuk memperbaiki ketahanan jantung dan peredaran darah, maka kita harus melakukan latihan-latihan olahraga secara terus menerus dan teratur paling sedikit 20-30 menit, pada keadaan denyut jantung $70 \%$ dari denyut jantung yang maksimal. Oleh karena itu, diharapkan manusia selalu melakukan aktivitas gerak khususnya pada pembelajaran Penjaskes. Menurut Nurhasan (2001) bahwasanya kemampuan agar tubuh untuk menyesuaikan fungsi fisiologinya untuk mengatasi keadaan lingkungan atau tugas fisik yang memerlukan kerja otot secara cukup efisien, tak mengalami kelelahan yang berlebihan. Dengan demikian jika kondisi kebugaran baik maka tubuh akan dapat bekerja dalam waktu yang lama. Catron dan Allen (dalam Sujiono, 2009) mengemukakan bahwa kemampuan motorik merupakan kesempatan yang luas untuk bergerak, pengalaman belajar untuk menemukan dan aktivitas sensor motorik termasuk penggunaan otot-otot kecil dan besar yang memungkinkan anak untuk memenuhi perkembangan perseptual motorik.

Di dalam dunia olahraga, gerak dasar selalu diterapkan dalam setiap mata pelajaran atletik. Penerapan gerak dasar lokomotor di sekolah disesuaikan dengan klasifikasi usia siswa yang terdapat perbedaan dalam tingkat kemampuan bergerak dan kemampuan dalam menerima instruksi gerak. Pada siswa kelas $3 \mathrm{SD}$ dengan klasifikasi usia sekitar 8-9 tahun gerak dasar lokomotor yang diterapkan pada pembelajaran pendidikan jasmani perlu adanya bimbingan dan latihan agar gerakan yang dilakukan baik dan benar. Gerak lokomotor atau disebut juga travelling diartikan sebagai gerakan berpindah tempat, seperti jalan, lari, dan lompat.

Selama ini, proses pembelajaran khususnya gerak dasar lokomotor belum dimodifikasi sesuai kebutuhan siswa sekolah dasar kelas bawah. Misalnya siswa hanya melakukan gerakan jalan, lari, loncat biasa tanpa dimodifikasi dalam bentuk permainan yang menarik sehingga hal tersebut dianggap kurang efektif karakteristik anak sekolah 
dasar pada umumnya memiliki kekhasan dalam bersikap yang diungkapkan dalam bermain. Karakteristik inilah yang harus diangkat untuk menjembatani antara keinginan guru dan murid. Dalam Bremer (2014) menyatakan bahwa guru Pendidikan Jasmani harus memanfaatkan hari-hari aktif sekolah, sebagai upaya untuk meningkatkan baik level kemampuan motorik dan aktifitas fisik siswa untuk membuat pondasi hidup yang aktif dan sehat salah satu solusi yaitu dengan menerapkan olahraga permainan.

Fakta lain yang ditemukan di sekolah juga menunjukkan bahwa banyak guru penjas yang melaksanakan proses pembelajaran dengan cara tradisional, dengan menitik beratkan materi dan tujuan pembelajaran yang berorientasi pada kecabangan olahraga. Sehingga secara tidak langsung guru dalam proses ini bukan memberikan pembelajaran tetapi lebih kepada melatih siswa untuk menguasai tugas gerak yang berupa teknik dasar olahraga. Padahal dalam pendidikan jasmani, siswa SD tidak diharuskan atau belum saatnya untuk menguasai teknik dasar tersebut, melainkan lebih menekankan pada pembelajaran komponen gerak dasar, yang didasari oleh konsep gerak yang benar (Mahendra, 2007).

Dari permasalahan permasalahan di atas, maka penting adanya sebuah model pembelajaran yang bisa menumbuhkan gerak dasar lokomotor siswa yang cocok untuk pembelajaran anak Sekolah Dasar selain untuk mengembangkan keterampilan siswa juga untuk mempermudah siswa memahami materi dengan perasaan senang dan antusiasme yang tinggi.Dari permasalahanpermasalahan di atas, maka penting adanya sebuah model pembelajaran yang bisa menumbuhkan gerak dasar lokomotor siswa yang cocok untuk pembelajaran anak Sekolah Dasar selain untuk mengembangkan keterampilan siswa juga untuk mempermudah siswa memahami materi dengan perasaan senang dan antusiasme yang tinggi. Bermain sebagai kegiatan yang bertalian dengan keseluruhan komponen dalam diri anak, melalui permainan (pada saat anak bermain) anak terdorong mempraktikkan keterampilannya yang diarahkan pada perkembangan kognitif, perkembangan bahasa, perkembangan psikomotor, dan perkembangan fisik anak (Blegur 2017).

Pembelajaran atletik melalui pembelajaran permainan Formula 1 (Run, Jump, Throw) merupakan permainan yang sering dilombakan pada tingkat SD, seperti Popda, Porseni dan lain sebagainya. Keunggulan dari permainan ini yaitu seluruh aktivitas geraknya sangat erat kaitannya dengan semua komponen-komponen ranah yang terkandung dalam penjasorkes yaitu ranah psikomotorik, ranah afektif, dan ranah kognitif.

Pembelajaran menggunakan permainan Formula 1 (Run, Jump, Throw) ini diyakini mampu meningkatkan gerak lokomotor dan tingkat kebugaran jasmani pada siswa SD karena pembelajaran dibuat lebih menarik dan menyenangkan, yang sekaligus seluruh siswa melakukan aktifitas gerak sehingga dapat bermanfaat bagi perkembangan dan pertumbuhan siswa.

Terjemahan bebas dari pendapat Charles (dalam Inawati, 2012): " Formula 1 merupakan eventtim dimana setiap anggota tim harus menyelesaikan penuh event tersebut. Sampai dengan enam tim bisa bersaing pada waktu yang sama pada satu program.

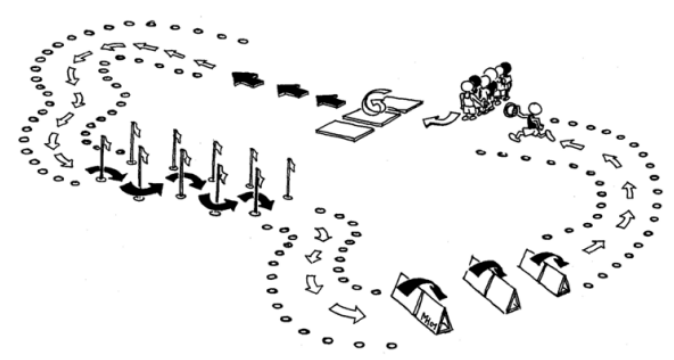

Gambar 1. Permainan formula 1

Permainan Formula 1 ini dimainkan dalam bentuk regu atau team, masingmasing team terdapat 5 siswa/ peserta didik. Kelima peserta didik ini berbaris berbanjar ke belakang di belakang garis start. Permainan ini dimainkan dengan sistem perlombaan atau sistem kompetitif. Kelima pelari ini melakukan satu persatu-satu bergantian dari garis start sampai garis finish. Sistematika permianan Formula 1 (Run, Jump, Throw) ini adalah sebagai berikut: Pelari pertama 
Jurnal Kejaora: Jurnal Kesehatan Jasmani dan Olah Raga

ISSN: 2541-5042 (Online)

ISSN: 2503-2976 (Print)

Volume 5 Nomor 2, Edisi November 2020

melakukan start, pada pos pertama pelari melakukan roll depan setelah itu melakukan tolakan dengan posisi berdiri ke arah depan dengan peluru modifikasi yang sudah tersedia pada garis tolakan pos pertama.

Kemudian siswa itu lari dengan jarak 7 $\mathrm{m}$ ke depan masuk menuju ke pos II, sebelum melakukan tolakan berikutnya di dalam pos II terdapat rintangan berupa banban lompatan, pelari harus melompati banban tersebut sebanyak tiga kali dengan menggunakan kedua kakinya. Sesampainya pada garis pergantingan rintangan, pelari menjumpai rintangan slalom yang harus dilewati pelari. Rintangan slalom berupa bendera berbaris yang jarak antar benderanya adalah $1 \mathrm{~m}$ dengan tinggi kurang lebih $1,5 \mathrm{~m}$, pelari harus menghindarinya dengan lari zig- zag sebanyak empat kali. Setelah sampai pada garis tolakan, pelari mengambil peluru modifikasi (kargel) yang sudah tersedia untuk kemudian ditolakan ke depan dengan gaya menyamping tanpa awalan yang jaraknya kira-kira $7 \mathrm{~m}$ dengan melewatkan peluru di atas mistar yang tingginya $3 \mathrm{~m}$. Setelah selesai menolak, pelari tersebut lari ke depan sejauh $7 \mathrm{~m}$ untuk menuju pos terakhir yaitu pos III, sebelum pelari melakukan tolakan berikutnya di dalam pos ketiga ini terdapat rintangan yang harus dilalui yaitu rintangan corong lompatan. Rintangan corong lompatan merupakan corong minyak yang berukuran besar yang dibariskan sebanyak tiga buah dengan jarak antar corong $1 \mathrm{~m}$, yang tinnginya kurang lebih $40-45 \mathrm{~cm}$.

Sesampainya di garis tolakan pelari tersebut mengambil peluru modifikasi (kargel) yang sudah tersedia, yang kemudian ditolakan ke depan dengan awalan gaya menyamping sejauhjauhnya dengan mengincar target berupa sasaran bernomor dimana semakin jauh sasaran akan semakin besar pula pointnya. Setelah melakukan tolakan dan peluru modifikasi (kargel) jatuh di atas tanah, pelari keluar lintasan untuk lari balik ke belakang menuju kembali garis start untuk memberi tanda kepada temannya (tos/bertepuk tangan) supaya segera berlari melanjutkannya.

\section{METODE}

Penelitian dan pengembangan atau Research and Development (R\&D), adalah suatu proses atau langkah-langkah untuk mengembangkan suatu produk yang telah ada (Sukmadinata, 2017). Penelitian ini menggunakan metode Research \& Development $(R \& D)$ dengan menggunakan prosedur pengembangan dari Borg\& Gall (1983) yang telah dimodifikasi yaitu 10 tahap, dengan dibatasi hanya sampai pada tahap ke-7. Penyederhanaan dan pembatasan terhadap sepuluh langkah menjadi tujuh langkah dikarenakan faktor keterbatasan tenaga,dana, dan waktu (Sugiyono, 2011). Adapun rancangan desain penelitian dan pengembangan dapat dilihan dari alur dibawah ini:

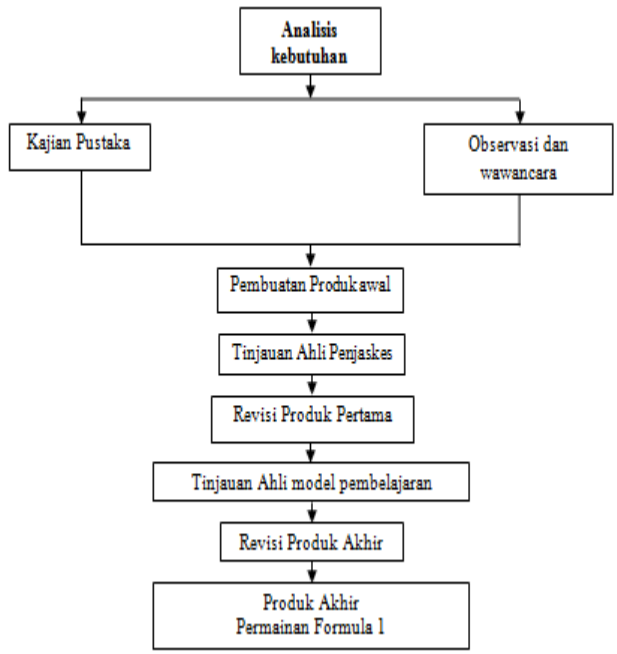

Gambar 2.Langkah-langkah Penggunaan Metode Research \& Development (R\&D)

Teknik analisis data yang digunakan dalam penelitian pengembangan ini adalah menggunakan teknik deskriptif berbentuk persentase. Jenis data yang diperoleh dalam penelitian dan pengembangan ini yaitu data kualitatif dan data kuantitatif. Data kualitatif berasal dari data masukan ahli terhadap model permainan formula 1. Data kuantitaatif diperoleh dari penilaian ahli penjas dan ahli pembelajaran terhadap model permainan formula 1 dan penilaian guru terhadap keefektifan model permainan formula 1. Draf permaianan dianggap layak untuk diuji cobakan dalam skala kecil apabila ahli telah 
Jurnal Kejaora: Jurnal Kesehatan Jasmani dan Olah Raga

ISSN: 2541-5042 (Online)

ISSN: 2503-2976 (Print)

Volume 5 Nomor 2, Edisi November 2020

memberi validasi dan menyatakan bahwa semua item kalsifikasi dalam skala nilai dinilai dengan memberi tanda centang.

\section{HASIL DAN PEMBAHASAN}

1. Data analisis kebutuhan

Data analisis kebutuhan dilakukan untuk mengetahui permasalahan yang terjadi pada proses pembelajaran Penjaskes serta solusi dalam permasalahan ini. Yang dilakukan dalam kegiatan ini adalah melakukan observasi, kegiatan proses pembelajaran dan menganalisis yang terjadi sesungguhnya di lapangan melakukan observasi pembelajaran dan melakukan studi pustaka atau kajian literatur.

Hasil awal observasi menemukan bahwa siswa kurang menggemari olahraga atletik karena proses pembelajaran yang diberikan terlihat kurang menarik minat siswa. Dari permasalahan ini perlu adanya suatu inovasi baru terutama dalam pembelajaran atletik agar ketika siswa menerima pembelajaran atletik tidak merasa terbebai dan lebih termotivasi. Inovasi yang harus dilakukan yaitu membuat suatu model permainan olahraga dengan memodifikasi sarana prasarana, peraturan permainan dan bentuk. Furqon (2006) Permainan dapat didefinisikan sebagai aktivitas yang dibatasi oleh aturan aturan yang lengkap dan terdapat suatu kontes di antara para pemain agar supaya menghasilkan hasil yang dapat diprediksi. Yoyo (2005) menyatakan dengan melakukan modifikasi, guru penjas akan menyajikan materi pelajaran yang sulit menjadi lebih mudah dan disederhanakan tanpa harus takut kehilangan makna dan apa yang akan diberikan. Anak akan lebih leluasa bergerak dalam berbagai situasi dan kondisi yang dimodifikasi. Winarno (2001) menyatakan modifikasi olahraga digunakan sebagai salah satu alternatif pendekatan dalam pembelajaran pendidikan jasmani.

Dari permasalahan diatas, peneliti melakukan inovasi pembelajaran dengan melakukan mengembangkan model pembelajaran permainan Formula 1 ( Run, Jump, Throw) yang sesuai bagi siswa Sekolah Dasar (SD). Harapan peneliti dari produk yang dihasilkan ini yaitu dapat membuat kualitas pembelajaran semakin 
Jurnal Kejaora: Jurnal Kesehatan Jasmani dan Olah Raga

ISSN: 2541-5042 (Online)

ISSN: 2503-2976 (Print)

Volume 5 Nomor 2, Edisi November 2020

Tabel 1. Dimensi dan Unsur Gerak Lokomotor Dan Kebugaran Jasmani

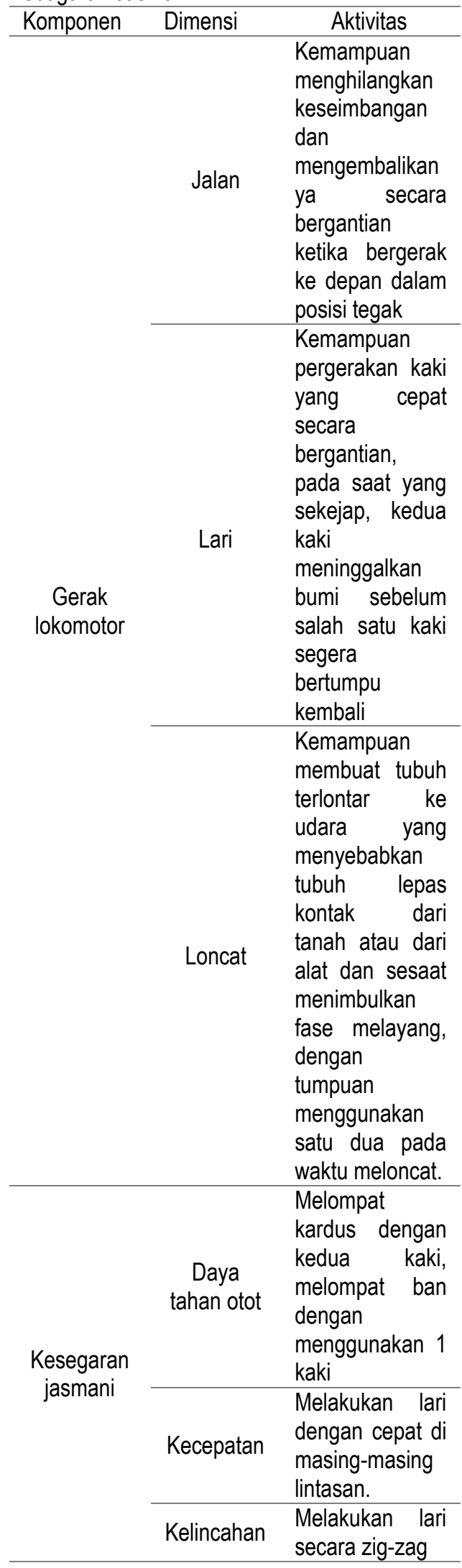

\begin{tabular}{cl}
\hline & $\begin{array}{l}\text { Menolak peluru } \\
\text { yang sudah } \\
\text { dimodifikasi ke } \\
\text { Ketepatan sasaran } \\
\text { yang ditentukan }\end{array}$ \\
\cline { 2 - 3 } & $\begin{array}{l}\text { Kegiatan } \\
\text { berguling di } \\
\text { matras }\end{array}$ \\
\hline
\end{tabular}

Permainan Formula 1 (Run, Jump, Throw) ini memiliki lapangan berupa lintasan yang panjangnya $40-45 \mathrm{~m}$ dan memiliki lebar masing-masing lintasan adalah $3 \mathrm{~m}$ yang dibagi menjadi dua lintasan. Permainan Formula 1 (Run, Jump, Throw) dimainkan dengan cara beregu atau tim, satu regu/tim terdiri dari 5 orang. Permainan Formula 1 (Run, Jump, Throw) ini dibagi menjadi tiga pos, masing-masing pos terdapat rintangan yang berbeda dimanapara pelari harus melewatinya dengan baik

\section{Validasi Produk Awal}

Pengembangan permainan Formula 1 (Run, Jump, Throw) pada pembelajaran atletik untuk siswa Sekolah Dasar perlu divalidasi oleh para ahli yang sesuai dengan penelitian ini. Peneliti melibatkan 2 (dua) orang ahli Penjas yang berasal dari guru dan Dosen Penjas dan 1 (satu) orang ahli pembelajaran yang juga berasal dari Dosen Penjas.

Peneliti memberikan draf produk awal permainan formula 1 ( Run, Jump, Throw) dengan menambahkan lembar evaluasi untuk ahli penjas dan ahli pembelajaran. Lembar evaluasi berisi beberapa aspek yaitu kualitas model pembelajaran, saran dan komentar dari ahli penjas dan ahli pembelajaran. Lembar evaluasi berupa nilai dari beberapa aspek kualitas dari pengembangan model pembelajaran formula 1 dengan menggunakan skala nilai 1 sampai dengan 5 .

\section{Deskripsi data Validasi Ahli}

Hasil yang diperoleh dari validasi ahli yaitu berupa data dari pengisian lembar evaluasi yang nantinya akan digunakan sebagai pedoman apakah model ini dapat dilanjutkan ke uji coba skala kecil dan uji coba lapangan. Berdasarkan hasil evaluasi dari validasi ahli didapatkan rata-rata 4 (empat) 
Jurnal Kejaora: Jurnal Kesehatan Jasmani dan Olah Raga

ISSN: 2541-5042 (Online)

ISSN: 2503-2976 (Print)

Volume 5 Nomor 2, Edisi November 2020

dan masuk dalam kategori "baik" sehingga permainan olahraga formula 1 dapat dilanjutkan ke uji coba skala kecil. Saran dan komentar pada produk model permainan formula 1 sangat diperlukan dalam melakukan perbaikan terhadap model

pembelajaran atletik tersebut. Dengan kriteria tidak baik (nilai 1), Kurang baik (nilai 2), Cukup baik (nilai 3), baik (nilai 4), dan sangat baik (nilai 5).

Tabel 2. Hasil Lembar Evaluasi Dari Ahli Penjas Dan Ahli Pembelajaran

\begin{tabular}{cccc}
\hline \multirow{2}{*}{ Nilai Akhir } & \multicolumn{3}{c}{ Skor Penilaian Ahli Penjas dan Ahli Pembelajaran } \\
\cline { 2 - 4 } & Ahli Penjas 1 & Ahli Penjas 2 & Ahli Pembelajaran \\
\hline Jumlah Skor & 72 & 73 & 75 \\
\hline Rata-Rata & 4,2 & 4,3 & 4,4 \\
\hline $\begin{array}{c}\text { Presentase rata- } \\
\text { rata }\end{array}$ & 85 & 86 & 88 \\
\hline
\end{tabular}

\section{Revisi Desain}

Kelayakan produk tidak terlepas dari masukan dan saran oleh para ahli. Perbaikan-perbaikan yang dilakukan terhadap produk yang dikembangkan berpedoman dari masukanmasukandan saran yang diperoleh dari para ahli validasi. Namun produk yang dihasilkansudah layak dapat dilanjutkan ke tahap berikutnya.

\section{Uji Coba Produk}

Uji coba produk dilakukan dengan 2 cara yaitu, uji coba kelompok kecil dan uji coba lapangan.

a. Uji Coba Skala Kecil

Uji skala kecil dilakukan bertujuan untuk mengetahui dan menganalisis berbagai permasalahan seperti kekurangan dan keefektifan model pembelajaran ini saat dipraktekkan kepada siswa. Selain itu uji skala kecil ini juga untuk mengetahui tanggapan awal dari produk yang dikembangkan. Uji skala kecil ini juga bertujuan untuk mengetahui peningkatan denyut nadi siswa sebelum dan sesudah melakukan permainan formula 1. Data uji coba kelompok kecil dihimpun melalui lembar evaluasi yang berupa kuesioner. Dari hasil tersebut didapatkan rata-rata sebesar $86 \%$, sehingga dapat disimpulkan permainan modifikasi permainan 1 dapat digunakan pada siswa SDN 1 Mangaran Kabupaten Situbondo.Uji coba kelompok kecildilakukan untuk mewakili populasi target pada 10 siswa kelas V. Berdasarkan hasil uji lapangan/skala kecil dapat disimpulkan bahwa dari aspek kognitif, afektif dan psikomotorik didapatkan hasil presentase dengan rata-rata cukup tinggi, dengan kriteria baik dan dapat dilihat di tabel dibawah ini:

Tabel 3. Rekapitulasi Presentase Kuesioner Siswa Skala Kecil

\begin{tabular}{llll}
\hline No & Aspek & Hasil & Kriteria \\
\hline 1 & Psikomotor & 89 & Sangat Baik \\
\hline 2 & Afektif & 88 & Sangat Baik \\
\hline 3 & Kognitif & 88 & Sangat Baik \\
\hline Rata-rata & 89 & Sangat Baik \\
\hline
\end{tabular}

Berdasarkan nilai rata-rata diatas dihasilkan $89,75 \%$ pada uji coba kelompok kecil. Hal ini menunjukkan model pembelajaran permainan formula 1 digemari dan disenangi oleh siswa SD. Di lihat dari pembelajaran siswa melakasanakan semua kegiatan atletik tidak merasa ditekan oleh guru, Riang gembira selalu ingin mencoba dan siswa sangat antusias setiap melakukan gerakan-gerakan atletik. Dengan demikian model pembelajaran permainan formula 1 yang telah di uji cobakan pada uji coba kelompok kecil dapat dipergunakan pada uji coba kelompok besar.

\section{b. Uji Coba Skala Besar}

Berdasarkan hasil uji lapangan/skala besar dapat disimpulkan bahwa dari aspek kognitif, afektif dan psikomotorik didapatkan hasil presentase dengan rata-rata cukup tinggi, dengan kriteria baik dan dapat dilihat di tabel dibawah ini: 
Tabel 4. Rekapitulasi Presentase Kuesioner Siswa Skala Besar

\begin{tabular}{llll}
\hline No & Aspek & Hasil & Kriteria \\
\hline 1 & Psikomotor & 90 & Sangat Baik \\
\hline 2 & Afektif & 91 & Sangat Baik \\
\hline 3 & Kognitif & 91 & Sangat Baik \\
\hline Rata-rata & 91 & Sangat Baik \\
\hline
\end{tabular}

Berdasarkan hasil kuesioner pada uji coba lapangan skala besar didapat rata-rata presentase $91 \%$. Berdasarkan kriteria yang ditentuan maka pengembangan model permainan formula 1 ini memenuhi kriteria "digunakan", sehingga dapat disimpulkan model pembelajaran permainan formula 1 dapat digunakan untuk siswa kelas V SDN 1 Mangaran Kabupaten Situbondo

\section{Revisi Produk}

Berdasarkan hasil uji coba produk, apabila respon siswa mengatakan bahwa produk ini menarik, maka dapat dikatakan bahwa produk model permainan ini telah selesai dikembangkansehingga menghasilkan produk akhir. Jika produk belum sempurna maka hasil dari ujicoba ini dijadikan bahan perbaikan dan penyempurnaan produk yang dibuat, sehinggadapat menghasilkan produk akhir berupa model permainan formula 1 dengan menggunakanyang dihasilkan adalah layak dan sangat menarik Dalam permainan Formula 1 terdapat beberapa ranah penjas, yaitu :

a. Kognitif, selama permainan ini berlangsung kemampuan pemahaman siswa terhadap aturan permainan dan strategi yang digunakan siswa saat bermain sangat baik itu terlihat dari hasil kuesioner siswa yang mendapat rata-rata $89 \%$.

b. Afektif, selama permainan ini berlangsung antusias siswa sangat besar itu terlihat dari kuesioner siswa dan mendapat ratarata $90 \%$ itu menunjukkan kriteria sangat baik.

c. Psikomotor, selama permainan berlangsung siswa terus bergerak dan keberhasilan pada aspek ini terlihat dari kuesioner siswa dengan kriteria menunjukan baik (90\%).
Permainan ini merupakan bentuk modifikasi dari permainan yang sudah ada. Pengembangan permainan formula 1 untuk mengembangkan kemampuan gerak dasar lokomotor dan kebugaran jasmani ini merupakan upaya dalam memenuhi standar kompetensi yang berkaitan dengan mempraktikan gerak dasar ke dalam permaian sederhana/aktivitas jasmani dan nilai yang terkandung didalamnya.

Bentuk permainan yang telah tersusun, secara umum menggambarkan atau mengakomodasi macam-macam gerak dasar lokomotor dan kebugaran jasmani yang ada, diantaranya: jalan, lari, loncat, kelincahan, ketepatan, keseimbangan. Bentuk- bentuk permainan formula 1 tersebut, disusun melalui beberapa tahapan pengembangan, diantaranya: data analisis kebutuhan, desain produk awal, validasi produk awal, deskripsi data validasi ahli, revisi desain, uji coba produk, revisi produk.

Pemanfaatan model permainan formula 1 yang telah dikembangkan, harus disesuaikan dengan kondisi setiap sekolah. Beberapa perbaikan dengan penyesuaian harus dilakukan agar model yang telah tersusun ini lebih sesuai dengan bermanfaat bagi guru penjas dan siswa.

Dalam pembelajaran penjaskes, aktivitas gerak wajib dihadirkan di setiap pembelajaran terutama gerak lokomotor yang tentunya akan berpengaruh terhadap tingkat kesegaran jasmani siswa. Kedua faktor tersebut memiliki peran penting terhadap kondisi fisik siswa. Apabila kondisi fisik siswa terganggu (sakit) maka siswa tidak dapat berkonsentrasi dalam mengikuti proses pembelajaran dengan baik. jika kondisi ini terus berlangsung,akan sangat mungkin prestasi siswa akan mengalami penurunan.

Slameto (2010) menjelaskan bahwa salah satu faktor pendukung belajar adalah faktor kesehatan. Sehat berarti dalam kondisi baik segenap badan beserta bagianbagiannya atau bebas dari penyakit.Kesehatan adalah keadaan atau hal sehat.Kesehatan seseorang berpengaruh terhadap belajarnya. Proses belajar seseorang akan terganggu jika kesehatan seseorang terganggu, selain itu dia juga akan cepat lelah, kurang bersemangat, udah 
Jurnal Kejaora: Jurnal Kesehatan Jasmani dan Olah Raga

ISSN: 2541-5042 (Online)

ISSN: 2503-2976 (Print)

Volume 5 Nomor 2, Edisi November 2020

pusing, ngantuk jika badannya lemah, kurang darah ataupun ganguan-gangguan atau kelainan-kelainan fungsi alat inderanya serta tubuhnya.

\section{KESIMPULAN}

Produk akhir dari kegiatan penelitian pengembangan ini adalah model pembelajaran formula 1 (run, jump, throw)yang merupakan produk dari pengembangan model pembelajaran gerak dasar atletik. Model pembelajaran ini dilaksanakan di SDN 1 Mangaran Kabupaten Situbondo yang sekolahnya tidak memiliki halaman cukup luas dan sarana prasarana olahraga yang kurang memadai. Berdasarkan data hasil uji lapangan dan data hasil kuesioner (meliputi aspek psikomotorik, kognitif, dan afektif) bahwa secara keseluruhan model pembelajaran ini memiliki kategori baik. Produk model pembelajaran formula 1 sangat efektif dan sesuai dengan karakteristik siswa kelas V SD karena dalam model permainan ini siswa terus melakukan berbagai macam gerakan seperti berjalan, berlari, melompat, melempar dan melakukan roll depan. Model permainan formula 1 ini dapat meningkatkan kondisi fisik siswa, komponen yang terlibat dalam model permainan ini yaitu: (1) kekuatan kaki saat berlari, (2) kecepatan pada saat berlari, (3) kelincahan pada saat berlari zig-zag, (4) daya ledak pada saat melompat rintangan kardus, (5) daya tahan pada saat melakukan permainan.

\section{DAFTAR PUSTAKA}

Badan Standar Nasional Pendidikan. (2006). Lampiran Standar Isi Pendidikan Jasmani dan Kesehatan. Jakarta:BSNP

Blegur, J., et al. (2017). Permainan Kecil: Teori dan Aplikasi. Kupang: Jusuf Aryani Learning

Borg, W.R. \& Gall, M.D. Gall. (1983). Educational Research: An Introduction, Fifth Edition. New York: Longman

Bremer, E. \& Lloyd, M. (2014). The Importance of Fundamental Motor Skill Proficiency for PhysicalActivity in Elementary School Age Females. 